\title{
KONSEP THEOSIS DALAM 2 PETRUS 1:4 DAN IMPLIKASINYA BAGI JEMAAT AWAM MASA KINI
}

\author{
Pilipus Kuiyok Sajijilat*1 \& Hendi Wijaya ${ }^{2}$ \\ ${ }^{1,2}$ Sekolah Tinggi Teologi Soteria Purwokerto \\ *sajijilat.mentawai@gmail.com \\ hendi@sttsoteria.ac.id
}

\begin{abstract}
The concept of Theosis is an important teaching that must be known to believer in Christ, because Theosis is the ultimate goal of human life, which is united with God, and the central core of the joyous message of the gospel is that we are called to share in God's life. The method of writing this article is a type of conceptual article or thought-provoking article (not a research article) which is an analysis of thoughts on the problem phenomena that arise. By using exegesis methods and other text comparisons, Theosis is obtained when humans live in God. Living in God means loving one another, and living in the light, then becoming similar and in line with God and purifying ourselves of all the passions of the world. There is no human who can experience Theosis if he does not live in God, become like and in the image of Christ and purify himself from all the passions of the World.
\end{abstract}

\section{Keywords: Living in God, similar and in the image of Christ and purifying ourselves.}

\begin{abstract}
Abstrak
Konsep Theosis merupakan satu pengajaran penting yang harus diketahui oleh setiap orang percaya kepada Kristus, karena Theosis merupakan tujuan akhir hidup manusia, yakni menyatu dengan Allah, dan inti utama berita sukacita dari Injil yaitu kita dipanggil untuk ikut ambil bagian dalam hidup-Nya Allah. Metode penulisan artikel ini adalah jenis artikel konseptual atau artikel hasil pemikiran (bukan artikel hasil penelitian) merupakan analisa pemikiran terhadap fenomena-fenomena masalah yang muncul. Dengan menggunakan metode eksegesis dan komparasi teks lain, maka Theosis didapatkan ketika manusia tinggal di dalam Allah. Tinggal di dalam Allah berarti saling mengasihi, dan hidup di dalam terang, kemudian menjadi serupa dan segambar dengan Allah dan menyucikan diri dari segala nafsu dunia. Tidak ada manusia yang dapat mengalami Theosis kalau tidak tinggal di dalam Allah, menjadi serupa dan segambar dengan Kristus dan menyucikan diri dari segala hawa nafsu Dunia.
\end{abstract}

Kata kunci: Tinggal di dalam Allah, Serupa, Segambar dengan Kristus, Menyucikan diri. 


\section{PENDAHULUAN}

Theosis merupakan salah satu pengajaran yang sangat penting dalam kehidupan kekristenan. Ada dua alasan yang mendasar mengapa begitu penting pengajaran ini. Pertama Theosis adalah tujuan akhir kehidupan manusia, dimana manusia akan kembali kepada gambar dan rupa yang sesungguhnya, seperti yang dituliskan oleh Anthony dalam Philokalia, "The goal Orthodox spiritualty very simply, is the attainment of union with God and consequently theosis or deification", . Ia menekankan bahwa, "theosis is our purpose and goal in life. ${ }^{2}$ Bahkan dari kalangan Buddhism menekankan hal yang sama misalnya, Zen Buddhism mengatakan, "In the beginning there was nothing. The purpose of life is to achieve union with nothingness. "3 Jadi, kita harus mengetahui tujuan akhir kehidupan kita sebagai manusia, yaitu menyatu dengan Kristus.

Kedua, Theosis merupakan inti utama berita sukacita dari Injil yaitu kita dipanggil untuk ikut ambil bagian dalam hidup-Nya Allah. ${ }^{4}$ Injil adalah kabar baik tentang keselamatan dari Yesus Kristus kepada semua orang. William G. Morrice menyatakan bahwa, "The whole message of the New Testament is good news of great joy for all people (cf. Lk. 2:10). Christianity is a message of joy from beginning to end." Lebih lanjut Morrice menulis, "Joy is more conspicuous in Christianity than in any other religion and in the Bible than in

${ }^{1}$ Anthony M. Coniaris, Philokalia: The Bible of Ortodox Spirituality (Minneapolis: Light and Publishing Company, 1998), 483.

${ }^{2}$ Ibid., 468.

${ }^{3}$ Ibid., 520 .

${ }^{4}$ Ibid., 492.

${ }^{5}$ William G. Morrice, Joy in the New Testament (Grand Rapids: William B. Eerdmans, 1984), 75.

108 | Vol. 4 No. 2 (Desember 2020) any other literature."6 Bahkan Morrice menegaskan, "Jesus himself is the supreme example for us to follow in this respect, as in other ways, too. He was indeed "the Man of Joy."7 James Martin juga menyatakan, "Joy has an object and that object is God. The ultimate response to the good news is joy, one that is lasting and can endure even in the midst of difficulties. "8 Dan Michael Fallon mengutip Paus Francis menyatakan bahwa, "The joy of the Gospel fills the hearts and the lives of all who encounter Jesus. Those who accept this offer of salvation are set free from sin, sorrow, inner emptiness and loneliness."9 Injil membawa sukacita bagi semua orang percaya.

Berdasarkan uraian tersebut bahwa Theosis merupakan pengajaran yang penting maka peneliti melihat di dalam kehidupan kekristenan masa kini, tidak lagi memperhatiakan pengajaran-pengarajan pokok seperti ini. Misalnya, dari alasan pertama mengapa pentingnya pengajaran Theosis yaitu tujuan akhir kehidupan manusia. Ketika kita mengetahui tujuan akhir kehidupan kita maka kita tidak lagi hidup ugal-ugalan dalam segala hal. Namun kenyataannya banyak orang tidak tahu tujuan kehidupan mereka sehingga kehidupannya mudah terbawa arus dan

${ }^{6}$ William G. Morrice, Joy in the New Testament (Grand Rapids: William B. Eerdmans, 1984), 152.

${ }^{7}$ Ibid.

${ }^{8}$ James Martin, "Have Faith in Joy." America 209, no. 19 (December 23, 2013), 13-16. Dikutip dalam sebuah disertasi Konsep Sukacita Di dalam Surat Filipi: Sebuah Pendekatan Integrasi Antara Analisis Wacana Dan Rentangan Semantis oleh Hendi tahun 2016. 2.

${ }^{9}$ Michael Fallon, M.S.C. "'The Joy of the Gospel-Some Points." Compass 49, no. 2 (Winter, 2015): $\quad 34 ; \quad$ tersedia di http://search.proquest.com/docview/1703341415?ac countid=25704; Internet; diakses tanggal 10 Februari 2016. 
dengan mudah melakukan tindakan fatal, misalnya bunuh diri. ${ }^{10}$ Menurut berita, awal tahun 2018 di Indonesia diawali dengan banyak deretan peristiwa bunuh diri. ${ }^{11}$ Hal ini, peneliti melihat bahwa dengan tidak adanya tujuan kehidupan yang pasti sehingga mudah mengakhiri hidupnya

\footnotetext{
${ }^{10}$ Seorang pemuda asal Sukabumi, Jawa Barat, tewas gantung diri di Pabrik Roti Mandiri, Jalan AMD X, RT12/01, Petukangan Utara, Pesanggrahan, Jakarta Selatan. Zaenal Mutaqin (19) diduga nekat mengakhiri hidupnya lantaran diputusin pacarnya, https://www.sindonews.com. (di akses 3 Juli 2018)

${ }^{11}$ Pada tanggal 2 Januari 2018 seorang narapidana (napi) Rumah Tahanan (Rutan) Tanjungpinang bernama Muhammad Putra (32), ditemukan tewas gantung diri di dalam sel blok Penyengat. Jasadnya baru ditemukan saat petugas sedang melakukan patroli keliling. Petugas menemukan Putra tergantung dengan handuk di pintu sel. Ia diduga nekat bunuh diri karena tidak terima dengan putusan hukum yang dijatuhkan kepadanya di Pengadilan Negeri Tanjungpinang. Dirinya diputus bersalah dan dijatuhi hukuman 5 tahun penjara atas perkara pidana asusila. Pada tanggal 4 Januari 2018, Mahasiswa Universitas Diponegoro (Undip), Michelle Gloria Sondakh (23) ditemukan tewas usai terjatuh dari lantai 8 sebuah hotel di Jalan Gajah Mada Semarang. Korban diduga sengaja bunuh diri karena memiliki gangguan psikologis. Hal tersebut diperkuat dengan penemuan obat penenang di lokasi kejadian dan keterangan keluarga. Pada tanggal 5 Januari 2018 Agnes Veronica Ariyani Susanto (53) ditemukan tewas di parkiran Apartemen Puncak Permai, Jalan Darmo Permai 3, Surabaya, Jawa Timur, usai melompat dari jendela kamarnya di lantai 18 . Korban mengalami patah tulang pada kedua kaki dan tangan. Tak hanya itu, kepala korban juga pecah dan ditemukan luka-luka pada sekujur tubuhnya. Dan pada tanggal 8 Januari 2018 Meritha Vridawati (26), seorang pegawai bank BUMN asal Sleman Yogyakarta ditemukan tewas mengenaskan di got Jalan Boulevard Melati, tepatnya di depan Thamrin City, Tanah Abang Jakarta Pusat, sekira pukul 06.00 WIB. Meritha tewas setelah melompat dari lantai 10 Apartemen Cosmo Park, diduga aksi bunuh diri ini dilatar belakangi beban pekerjaan yang tak sanggup dilakoni korban. Korban meninggalkan suami dan anaknya yang baru berumur 9 bulan, https://news.okezone.com/read/2018/01/11/338/1843 562/ini-deretan-peristiwa-bunuh-diri-di-awal-2018 (diakses 3 Juli 2018)
}

dengan cara bunuh diri. Rick Warren, dalam bukunya yang berjudul "The Purpose Driven Life" menuliskan, "Hidup dengan tujuan adalah satu-satunya cara untuk benar-benar hidup" "12 bahkan Thomas Carlyne bersih keras menekankan akan pentingnya tujuan kehidupan. Ia mengatakan bahwa manusia yang tidak mempunyai tujuan adalah ibarat kapal tanpa kemudi, suatu kesia-siaan, kehampaan, bukan manusia yang sebenarnya. ${ }^{13}$

Oleh sebab itu, peneliti membuat satu penelitian dari surat 2 Petrus 1:4. Adapun penelitian ini, peneliti memakai metode analisis atau eksegesis. Metode analisis atau eksegesis adalah metode di mana untuk mendapatkan sebuat arti (meaning). Tujuannya agar apa yang dimaksud penulis kitab dapat dimengerti dengan jelas oleh sipembaca sehingga pesannya dapat tersampaikan dengan benar. Selain dari 2 Ptr 1:4, dalam perjanjian baru penulis mendapat 20 ayat yang memiliki makna yang sama dalam mencapai atau bahkan cara untuk mengalami Theosis, diantaranya, Yoh 1:14, Yoh 14:23, Yoh 15:5, Rom 8:1, Rom 8: 9, Rom 8: 11, Gal 2:20, 1 Kor 3:16, Gal 4:19, Rom 8:29, 1 Yoh 3:2, 1 Kor 15:49, 2 Kor 3:18, Kol 3:10, Efe 4:13, Efe 1:9-10, Efe 3:19, Yoh 17:2223, Yoh 1:12, Yoh 10:34.

\section{METODE}

Metode penulisan artikel ini adalah jenis artikel konseptual atau artikel hasil pemikiran (bukan artikel hasil penelitian) merupakan analisa pemikiran terhadap fenomena-fenomena masalah yang muncul.

\footnotetext{
${ }^{12}$ Rick Warren, The Purpose Driven Life (Jakarta: Immanuel Publishing house, 2002), 360.

${ }^{13}$ Ibid., 15.
} 
Selanjutnya bahwa Brown \& Campione mengatakan bahwa penulis meneliti bahanbahan literatur yang berkaitan dengan permasalahannya. Bahan yang dikumpulkan tentu saja berbagai hal adalah bahan-bahan yang mendukung dan menolak pemikiran yang sedang penulis kaji tetapi bahan mendukung yang berupa hasil penelitian atau artikel atau buku dapat digunakan dalam artikel konseptual. Artikel konseptual berbicara bukan sekadar kumpulan kutipan dari sejumlah artikel, tetapi memasukan memikiran kritis penulisanya. ${ }^{14}$

\section{Analisis Teks 2 Petrus 1:4}

Teks

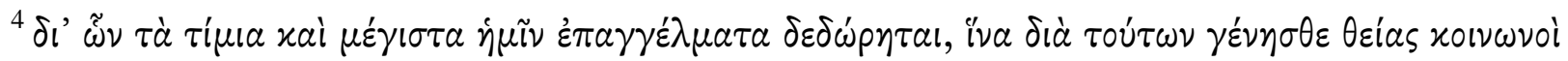

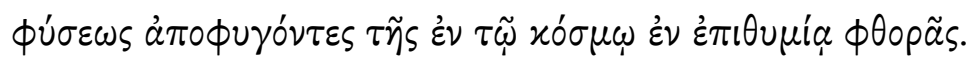

Syntactic Form

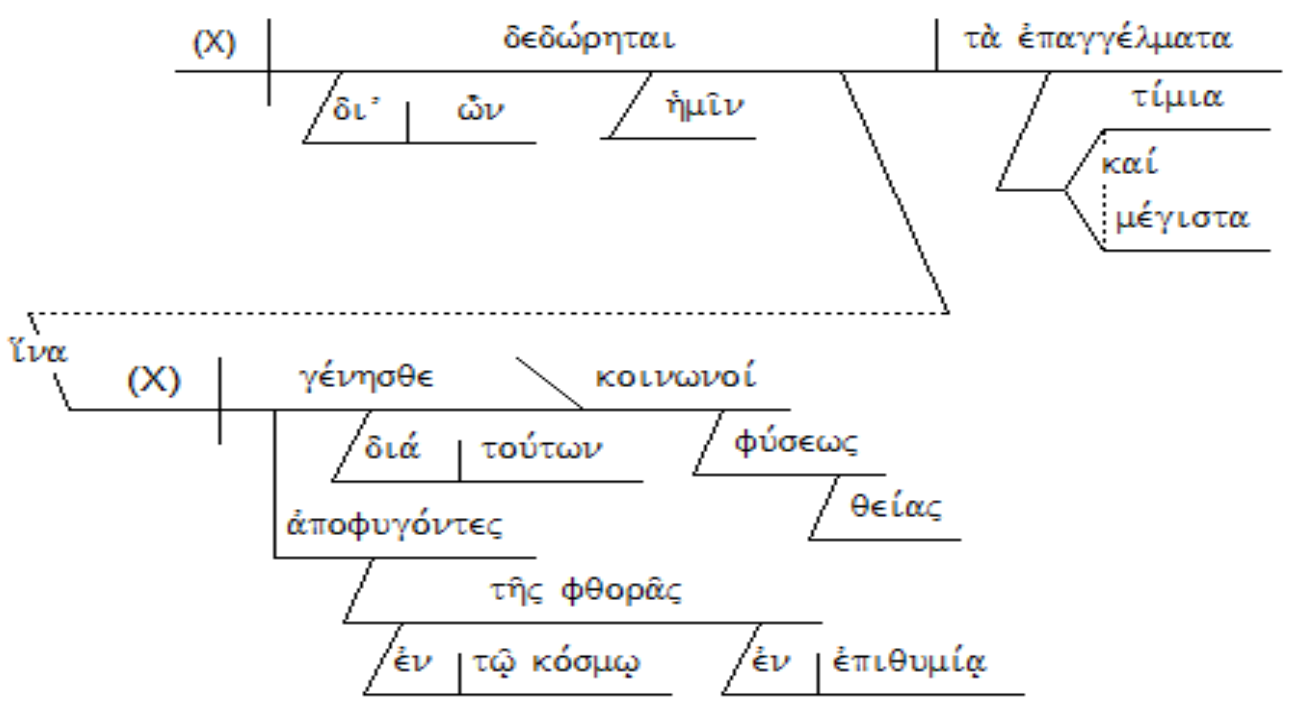

Penjelasan Teks

Subjeknya adalah Ia i் $\mu \tilde{v}$ yang diambil dari turunan kata $\dot{\varepsilon} \gamma \omega \dot{~ y a n g}$ artinya 'the Father

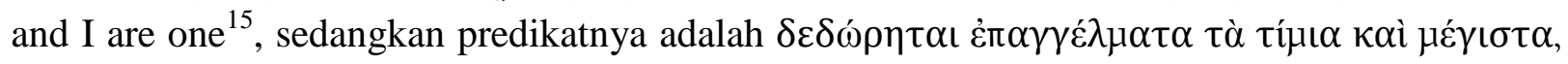

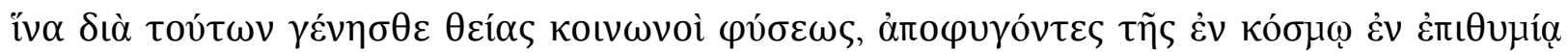
$\varphi \theta o \rho \tilde{\alpha}$. Terjemahan Literal: Dengan jalan itu diberikan kepada kita janji-janji yang besar dan berharga, bahwa dengan ini kamu dapat mengambil bagian dalam kodrat ilahi, supaya luput dari kebinasaan dunia dan hawa nafsu.

\section{Outline Konsep}

Ide Utama: Mengambil bagian dalam kodrat Ilahi Ide pendukung:

1. Janji yang besar dan berharga (kehidupan kekekalan).

2. Luput dari kebinasaan dunia dan Luput dari hawa nafsu.

${ }^{14}$ A.L. Brown \& J.C. Campione (1986), "Psychological Theory and the Study of Learning Disabilities". American Psychologist, 41(10), 1059-1068. https://doi.org/10.1037/0003-066X.41.10.1059.

${ }^{15}$ Lexicon

110 | Vol. 4 No. 2 (Desember 2020) 
Semantic content

Surat ini ditulis oleh Rasul Petrus, yang merupakan surat terakhir dari tulisannya, sebab diduga ia tidak lama lagi hidup, ${ }^{16}$ dan surat ini ditulis di Roma jika dibandingkan dengan surat yang pertama dari tulisannya. ${ }^{17}$ Pada tulisan Petrus yang kedua diawali dengan panggilan dan pilihan Allah, sehingga pada ayat 4 menekankan bahwa kita akan mengambil bagian dalam kodrat Ilahi. Kata $\theta$ cías menurut Low Nida Lexicon adalah pertaining to having the nature of God atau divine of God. ${ }^{18}$

Berdasarkan pengertian tersebut komitmen ilahi yang telah diberikan secara umum ini, orang percaya menjadi ikut memperoleh bagian di dalam harta yang paling kaya, yaitu sifat dan hidup Allah. "jika orang tidak memiliki Roh Kudus, ia bukan milik Kristus" (Roma 8:9). Hidup baru dengan Roh ini tidak lain dari pada "Kristus di dalam dirimu" yang diperlukan adalah sebuah penyerahan diri, suatu ketaatan, suatu perjalanan hidup (Galatia 5:25). Kehidupan yang baru ini memindahkan kita dari kehidupan maut yang berupa keterikatan pada keinginan nafsu (Roma 8:11-13). ${ }^{19}$

Menurut Christopher Green dalam tafsiran The Message of 2 Peter \& Jude, bahwa ada dua janji yang akan kita alami dari Tuhan yakni "promise of glory dan

\footnotetext{
${ }^{16}$ LAI, 2 Petrus 1:14.

${ }^{17}$ A. Simanjuktak, dkk; Tafsiran Alkitab Masa Kini 3 Kejadian- Wahyu (Jakarta: Yayasan Komunikasi Bina Kasih, 2006), 838.

${ }^{18}$ Low Nida Lexicon

${ }^{19}$ Charles F. Pfreiffer dan Everett F. Harrison, Tafsiran Alkitab Wycliffe volume 3 Perjanjian Baru (Malang: Yayasan Penerbit Gandum Mas, 1962), 1022.
}

promise of escape". ${ }^{20}$ Janji pertama kita mengambil kodrat ilahi, di dalam roh, terang dan kasih, ${ }^{21}$ sementara janji yang kedua kita diluputkan dari kuasa gelap. Bahkan yang mempersatukan kita kembali dengan Tuhan dari keterpisahan kita dengan sang pencipta atas dosa. Demikian yang dituliskan Christopher: Event though there are not more animal sacrifices, it will design awesome buildings, and perform mystical music and uplifting spectacle, conveying a sense of mystery and dread. Such an approach can leave a Christian feeling that God is still as unapproachable as ever, except for a tiny spiritual elite, and that the way to please this distance God is to follow a strict regiment of rules as if to appease the God who was not fully appeased by the death of his Son. ${ }^{22}$

Kata "dengan jalan itu" menunjuk pada Kristus, karena jika dikaitkan dengan 2 Ptr 1:3, yang menyebutkan "kuasa ilahi", maka kuasa itu sendiri adalah Kristus. Menurut Kamus Besar Bahasa Indonesia, kuasa memiliki makna kata yang sama dengan "kekuatan", sementara sinonim dari kata kekuatan adalah tenaga atau energi. Energi tersebut keluar dari diri-Nya Allah dan yang keluar dari diri Allah adalah Firman-Nya. Kemudian Firman itu telah menjadi manusia yaitu Kristus.

Petrus menekankan bahwa karena mutu kehidupan Tuhan Yesus orang percaya dapat menerima perjanjian untuk mendapat bagian dalam kodrat Allah. ajaran

${ }^{20}$ Dick Lukas and Christopher Green, The Message of 2 Peter \& Jude (England: Inter Varsity Press, 1995), 51-52.

${ }^{21}$ James Hastings, D.D, The speaker Bible The Epistle of James (USA: Baker House Company, 1987), 320.

${ }^{22}$ Dick Lukas and Christopher Green, The Message of 2 Peter \& Jude (England: Inter Varsity Press, 1995), 52. 
tersebut adalah ajaran roma 6, yaitu bahwa berdasarkan pribadi Kristus dan kemanunggalan dengan-Nya yang diwujudkan dalam iman, maka orang Kristen di dunia ini mengalami hidup yang luput dari dosa dan kecemarannya, sehingga makin bertumbuh menyerupai kehidupan Tuhan Yesus. janji-janji; satu per satu dikemukakan oleh Petrus dalam 1 Ptr 1:3-5; (hidup penuh pengharapan, tidak dapat binasa) 1 Ptr 2:9, (keluar dari kegelapan kepada terang). olehnya mengandung arti, jika kamu hidup oleh janji-janji tersebut. ${ }^{23}$

Dari Janji tersebut memberikan gambaran akan hidup kekal (1 Yoh 2:25), dan hidup kekal itu hanya di dapat ketika percaya bahwa satu-satunya Allah yang benar dan mengenal Kristus (Yoh 17:3). Oleh sebab itu Kristus yang adalah janji telah turun ke dunia untuk menghampiri manusia yang berdosa sehingga manusia memperoleh hidup kekal (Yoh 3:16).

\section{Konsep Teologis}

Theosis akan dialami oleh setiap manusia yang percaya kepada Allah Tritunggal setelah kematian, yang dikerjakan dan dipersiapkan saat ini, bukan besok atau lusa. Namun dampaknya akan dialami oleh manusia setelah manusia dinyatakan sama seperti Kristus. Pertanyaanya apa yang harus dikerjakan manusia untuk mencapai Theosis? Pertama, manusia harus tinggal di dalam Allah melalui energi Ilahi, yang dapat diwujudkan dengan saling mengasihi (2 Ptr 1:7) dan hidup di dalam terang.

Satu bagian firman Tuhan yang memberikan jawaban mengapa harus saling mengasihi? Mengasihi merupakan hukum yang utama dan terutama yang di ringkas

\footnotetext{
${ }^{23}$ A. Simanjuntak dkk, Tafsiran Alkitab Masa kini jilid 3, (Jakarta: Yayasan Komunikasi Bima Kasih, 1974), 843.
}

112 | Vol. 4 No. 2 (Desember 2020) oleh Kristus dari sekian banyak hukum Taurat. Dalam percakapan Yesus dengan ahli Taurat, yang ditulis oleh Injil Markus 12:29-31, yakni mengasihi Allah dan sesama manusia seperti diri sendiri. Sangat jelas bahwa mengasihi Allah berarti dikenal oleh Allah (1 Kor 8:3), dan berasal dari Allah (1 Yoh 4:7). Orang yang saling mengasihi memberikan gambaran kepada dunia bahwa Allah ada di dalam dia (1 Yoh $4: 12)$.

Sedangkan hidup di dalam terang artinya kehidupan yang sudah memisahkan diri dari kegelapan. Dengan ketidak layakan manusia karena dosa, sehingga manusia disebut manusia berdosa dan hidup dalam gelap. Maka dengan kuasa pengorbana Kristus menjadikan manusia layak dihadapan Allah dan dapat memisahkan diri dari kegelapan itu.

Kedua, menjadi serupa dan segambar dengan Kristus, artinya keserupaan yang dialaminya melalui kematian Kristus, supaya memperoleh kebangkitan. Sebab tanpa kematian tidak ada kebangkitan. Kematian yang dialami oleh manusia bukanlah kematian tubuh, tetapi kematian secara jasmani dan rohani, yakni mematikan hawa nafsu seperti yang dialami oleh Rasul Paulus.

Kemudian bagaimana cara untuk mengerjakannya? Satu cara yang dikerjakan manusia adalah menyucikan diri dari segala kecemaran dunia. Pada dasarnya manusia tidak bisa suci karena telah di cemari oleh berdosa, Rm 3:23, namun karena kasih Tuhan kepada manusia, dengan pengorbanan Kristus di Kayu salib, maka manusia dapat disucikan. Untuk menyucikan diri harus terlebih dahulu benar dihadapan Allah. Benar dihadapan Allah berarti sempurna tanpa cacat, serta melakukan kebenaran. Doa dan sakramen 
adalah alat menuju pembenaran untuk hidup kudus.

\section{Apa yang harus dikerjakan untuk mencapai Theosis: Tinggal di Dalam Allah Melalui Energi Ilahi}

Menurut Kamu Besar Bahasa Indonesia (KBBI), tinggal berarti masih tetap di tempatnya. Artinya dalam hal ini berdiam dalam satu ruang lingkup dan tetap berada di situ. Dengan demikian kata "di dalam" menggambarkan keberadaan kita yang dibatasi oleh satu tempat atau ruangan sehingga dikatakan bahwa sesuatu benda atau objek berada dalam ruangan itu atau tempat itu.

Namun pada bagian ini, Allah yang merupakan wadah atau tempat kita tinggal,bukanlah tempat yang pada umumnya diketahui oleh setiap orang, sebab Allah bukanlah tempat yang memiliki ukuran luas, Panjang dan tinggi, melainkan Allah adalah terang. ${ }^{24}$ Terang tersebut mengeluarkan cahaya yang tidak mampu di hampiri oleh manusia dengan tubuh jasmani. Tetapi dengan kehadiran Kristus yang merupakan cahaya itu sendiri, ${ }^{25}$ maka manusia dapat dimampukan untuk menghampiri- Nya karena hanya melalui Dialah manusia bisa datang kepada terang itu.

Pertanyaannya, bagaimana kita tetap tinggal di dalam Allah? Atau manunggal dengan Allah di dalam energi? Mengenai Energi Ilahi itu diajarkan demikian oleh Alkitab, (Yoh 1:18) "Tak seorangpun pernah melihat Allah...", (Mat 11:27) “...tidak seorangpun mengenal Bapa...,, (1 Kor 2:11) “...tidak ada orang yang tahu, apa yang terdapat di dalam diri Allah..."

\footnotetext{
${ }^{24}$ LAI, 1 Yoh 1: 5

${ }^{25}$ LAI, Ibr 1:3.
}

dan (1 Tim 6:16) “.....bersemayam dalam terang yang terhampiri. Seorangpun tak pernah melihat Dia, dan memang manusia tak dapat melihat Dia".

Ayat-ayat diatas menjelaskan bahwa Allah tak pernah dikenal, tak pernah dilihat, tak terselidiki, tak terselami, tak diketahui apa yang ada didalam diri- Nya, tak terhampiri, serta tak dapat dilihat manusia. Singkat kata, ayat-ayat diatas menunjukkan Allah itu tak dimengerti sama sekali keadaan- Nya oleh manusia. Allah itu begitu gaib dan misterius- Nya sehingga dijelaskan dengan kata- kata seperti itu. Namun demikian ada ayat-ayat lain dalam Alkitab yang mengatakan demikian “.....Ia tidak jauh dari kita masing-masing. Sebab di dalam Dia kita hidup, kita bergerak,kita ada...." ( Kis 17: 27-28) “... apa yang dapat mereka ketahui tentang Allah nyata bagi mereka.....apa yang tidak nampak daripadanya, yaitu kekuatanNya yang kekal dan keilahianNya, dapat nampak....dari karyaNya...." ( Rom 1:19-20), dan "Kudus, kudus kuduslah Tuhan semesta alam, seluruh bumi penuh kemuliaan-Nya" (Yesaya 6:3). ${ }^{26}$

Disini Allah disebutkan sebagai yang tak jauh dari manusia yang seolaholah berenang di dalam hadirat Allah sendiri, Allah nampak dari karya-Nya, dan kemuliaan Allah itu memenuhi seluruh bumi, yang berarti bumi itu dipenuhi dengan hadirat Allah. Mengapa ada keberadaan yang seolah-olah kontradiksi ini mengenai Allah? Ini bukan kontradiksi, namun dua cara hadirat Allah yang berbeda. Yang diatas menjelaskan Allah dalam kehadiranNya pada Diri-Nya sendiri, yaitu

${ }^{26}$ Arkhimandrit Bambang Dwi Byantoro, Gereja Orthodox Katolik dan Ajaran-ajarannya. Pdf.2007, 60. 
pada Esensi, Hakikat, atau zat Ke-Allah-anNya sendiri, yaitu keilahian dan kekuatanNya yang kekal. Ini memang tak dimengerti oleh manusia. Sedangkan kelompok kutipan yang kedua menjelaskan cara kehadiran Allah diantara makhluk-Nya dan kehadiran itu berwujud "Kemuliaan" yang memenuhi bumi, sehingga manusia dapat hidup, bergerak dan ada, dan kemuliaan itu nampak pada karya-karya Allah itu, artinya pada hasil aktivitas perbuatan Allah. ${ }^{27}$

Byantoro menjelaskan bahwa "Esensi Ilahi" adalah kehadiran Allah pada diriNya sendiri, atau hakekat Allah itu sendiri, dan "Energi Ilahi" adalah kehadiran Allah ditengah-tengah ciptaanNya, yaitu aktivitas perbuatanNya diluar "Esensi-Nya. Namun kedua-duanya adalah kehadiran yang nyata dari Allah itu sendiri. "Energi Ilahi" bukanlah sesuatu yang diciptakan Allah, namun "energi tak tercipta" yang mengalir keluar dari dalam esensi itu sendiri. ${ }^{28}$ Yang mengalir keluar dari esensi Allah sendiri adalah Firman-Nya. Firman tersebut yang menjadikan segala sesuatu ada (Kej 1:3, Rom 11:36, 1 Kor 8:6 dan Kol 1:17) dan firman itu berinkarnasi menjadi manusia yakni Yesus Kristus (Yoh 1:1;14). Tidak ad acara lain untuk tetap tinggal dengan Tuhan, selain menempel dan menyatu dengan Dia. Menyatu berarti menuruti dan melakukan semua yang di firmankan. Penekanan yang sama yang dituliskan oleh Gregory Palamas, demikian "By keeping the divine commandments. For the Lord has promised to manifest Himself to the man who keeps them, a manifestation He calls His own indwelling and that of the Father, saying, "If anyone loves Me, he will keep My word, and My Father will love

${ }^{27}$ Arkhimandrit Bambang Dwi Byantoro, Gereja Orthodox Katolik dan Ajaran-ajarannya. Pdf.2007, 60.

${ }^{28}$ Ibid., 60 him, and We will come to him and will make our abode with him" and "I will manifest Myself to him." And it is clear that in mentioning His "word", He means His commandments, since earlier He speaks of "commandments" in place of "word": "He who possesses and keeps My commandments, that is the man who loves $M e .^{\prime 29}$

Sangat jelas bahwa orang yang melakukan perintah Tuhan adalah orang yang mengasihi-Nya (Yoh 14:21). Dan orang yang mengasihi Allah berarti dikenal oleh Allah (1 Kor 8:3), dan berasal dari Allah (1 Yoh 4:7). Orang yang saling mengasihi memberikan gambaran kepada dunia bahwa Allah ada di dalam dia (1 Yoh 4:12). Rasul Yohanes menulis sebuah konsep yang begitu dalam tentang arti tinggal di dalam Allah atau hidup di dalam Allah. Ada dua poin utama tinggal di dalam Allah yaitu menyucikan diri dari dosa sebagai wujud hidup di dalam terang dan saling mengasihi sebagai wujud ketaatan kepada perintah Allah. Allah adalah terang ( 1 Yoh 1:5) sehingga dalam pemahaman yang lain seperti yang dituliskan oleh Hendi Wijaya bahwa: berada di dalam Allah berarti beada di dalam terang. Berada di dalam terang bearti hidup di dalam terang. ${ }^{30}$

Allah yang adalah terang sebetulnya merupakan konsep yang tidak asing lagi di dalam Perjanjian Lama, maupun Perjanjian Baru (Mzm 104:1,2; Kel 24:17, Yoh 12:46, Efe 5:13, dan Yak 1:17). Dan terang selalu dikontaskan dengan kata kegelapan. Jika dikaitkan dengan surat Yohanes yang pertama pada pasal dua ayat sembilan, maka kita mendapat jawaban bahwa

\footnotetext{
${ }^{29}$ John Meyendorff, Gregory Palamas The Triads (United States of America: Paulist Press, 1983), 60 .

${ }^{30} \mathrm{https}: / /$ hendisttrii.wordpress.com/2018/05/ 06/tinggal-di-dalam-allah/ (diakses 3 April 2019).
} 
kegelapan itu adalah orang yang tidak mempunyai kasih atau membenci saudaranya. $^{31}$ Kemudian dari beberapa eksegesis ayat pada bab II bahwa ketika kita tinggal di dalam Allah kita tidak lagi hidup di dalam daging melainkan di dalam Roh (Rom 8:9), di dalam Allah tidak ada lagi penghukuman (Rom 8:1), dan bahkan lebih lagi bahwa kita disebut bait Allah jika Roh Allah tinggal di dalam kita. Dari beberapa pemahanam yang disampaikan oleh penulis dari sekian kutipan mengenai tinggal di dalam Allah, maka penulis mendapatkan dua poin utama yang merupakan gaya hidup seseorang atau cara bagaimana hidup di dalam Allah, diantaranya:

\section{Saling Mengasihi.}

Mengasihi merupakan hukum yang utama dan terutama yang di ringkas oleh Kristus dari sekian banyak hukum Taurat. Dalam percakapan Yesus dengan ahli Taurat, yang ditulis oleh Injil Markus 12:29-31: "Yesus menjawab: Hukum yang terutama ialah: Dengarlah, hai orang Israel, Tuhan Allah kita, Tuhan itu esa. Kasihilah Tuhan Allahmu, dengan segenap hatimu dan dengan segenap jiwamu dan dengan segenap akal budimu dan dengan segenap kekuatanmu. Dan hukum yang kedua ialah: kasihilah sesamamu manusia seperti dirimu sendiri. Tidak ada hukum lain yang lebih utama dari pada kedua hukum ini.",32 Kesimpulan terakhir dari apa yang disampaikan Yesus yang merupakan penekanan penting, bahwa tidak ada hukum lain yang lebih utama dari pada kedua hukum ini. Dalam artian dua hukum itulah yang lebih tinggi dari pada hukum lain.

\footnotetext{
${ }^{31}$ https://hendisttrii.wordpress.com/2018/05/ 06/tinggal-di-dalam-allah/ (diakses 4 April 2019)

${ }^{32}$ LAI, Mrk 12:29-31.
}

Dari sudut pandang penulis mengapa kedua hukum itu lebih utama karena, tidak ada pembuhunan, pemerkosaan, pencurian bahkan kebencian jika kita semua orang saling mengasihi.

Seperti beberapa bulan yang lalu, yang dilansir oleh Ttibun-timur.com, terjadi pembunuhan di Palembang dikarenakan ujaran kebencian kepada korban (calon pendeta muda). ${ }^{33}$ Ini merupakan salah satu contoh, tidak adanya kasih di dalam diri kedua pelaku. Oleh sebab itulah setiap orang diharuskan untuk saling mengasihi. Orang yang saling mengasihi berarti orang yang melakukan firman Tuhan. Banyak orang yang berpuluh-puluh tahun menjadi Kristen dan merasa mengenal Allah tetapi sesungguhnya ia belum pernah benar-benar memahami kemenangan Kristus dalam hidupnya karena firman Allah tidak dikomunikasikan kepadanya secara pribadi sehingga bingung. Dan tidak heran, justru dosa dan kelemahan pribadinya tidak pernah terselesaikan sampai tuntas.

Yakub Susabda memberikan sebuah ilustrasi orang yang tidak dapat menuntaskan dosa dan kelemahan secara pribadi. Sebagai contoh, seorang pembantu rumah tangga yagn tidak pernah mengerti diskripsi kerjanya. Baru tiga menit mencuci piring, ia tiba-tiba tinggalkan piring-piring yang masih kotor itu, karena ingat, ia harus membersihkan lantai. Kemudian baru beberapa menit membersihkan lantai ia tiba-tiba ingat bahwa ia harus mencuci baju. Lalu mulailah ia mencuci baju, tetapi kemudian segera ia tinggalkan lagi kaena ia

\footnotetext{
${ }^{33}$ https://www.google.com/amp/makasar.tri bunnews.com/amp/2019/03/29/motif-rasa-bencijadi-alasan-2-pelaku-bunuh-telanjangi-pendetacantik-melinda-zidemi-fotonya ,(diakses 6 April 2019)
} 
ingat ia harus mulai masak. ${ }^{34}$ Demikianlah Susabda menggambarkan pola kehidupan banyak orang Kristen dengan Allah. Meraka menjadi kumpulan orang-orang panik yang sibuk mau meresponi firman Alla, tetapi tidak mengerti mana yang harus diprioritaskan terlebih dahulu. Akibatnya semua firman mau dilakukan dalam waktu yang sama sehingga tak satupun yang dilakukan sampai tuntas

Satu point penting yang disampaikan pada bagian ini oleh Yakub Susabda, bagaimana cara kita melakukan firman, yakni mengerjakan apa yang lebih prioritas. Bukan berarti ada sebagian firman Allah yang tidak perlu, melainkan semua firman Allah adalah perlu, baik untuk mengajar, menyatakan kesalahan, memperbaiki kelakuan, dan mendidik orang dalam kebenaran. ${ }^{35}$ Kita tahu bahwa setiap orang menghadapi persoalan dan pergumulan iman yang berbeda-beda. Bagi yang pergumulannya denga dosa tertentu seharusnya ia mengkonsentrasikan dirinya dalam penyelesaian dosa tersebut. Inilah yang dimaksud lebih prioritas.

Dalam pemahaman yang sama di yang disampaikan Oleh Yesus ketika ingin memberikan persembahan kepada Tuhan, sementara belum berdamai dengan saudaranya, maka terlabih dahulu yang harus dilakukan adalah berdamai dengan saudaranya, setelah itu barulah ia mempersembahkan persembahannya kepada Tuhan (Mat 5:24). Demikianlah proses untuk tinggal di dalam Allah dimana setiap orang harus mengasihi, dalam Perjanjian muncul 119 kata mengasihi ${ }^{36}$ dan

\footnotetext{
${ }^{34}$ Yakub Susabda, Mengenal dan Bergaul dengan Allah (Batam: Gospel Press, 2001), 43.

${ }^{35}$ LAI, 2 Tim 3:16.

${ }^{36}$ LAI, Mat 5:46 (2 kata); 6:24; 10: 37 (2 kata), Mrk 12:33 (2 kata), Luk 6:32 (4 kata); 7:5, 42; $16: 13$, Yoh $3: 35 ; 5: 20 ; 8: 42 ; 10: 17,11: 5 ; 13: 1(2$ kata), 34 (3 kata), 35; 14:15, 21 (3 kata), 23 (2 kata), 116 | Vol. 4 No. 2 (Desember 2020)
}

21 kata kasihilah. ${ }^{37}$ Ini membuktikan bahwa begitu pentingnya kita saling mengasihi, sebab Allah adalah kasih. ${ }^{38}$ Karena Tuhan terlebih dahulu telah mengasihi kita, mestinya kita harus mengasihi sesama sebagai wujud nyata kita mengasihi Tuhan.

Yakub Susabda dalam bukunya yang berjudul "Mengenal dan bergaul dengan Allah" menekankan bahwa salah satu pengenalan sejati akan Allah yang hidup selalu ditandai dengan kasih Allah. ${ }^{39}$ Bahkan Hendi mengatakan bahwa kasih adalah fondasi karena kasih itu kegenapan hukum Taurat (Rom 13:10). Dan Kristus datang menggenapi hukum Taurat (Mat 5:27). Demikianlah kita ketahui kasih Kritus, yaitu bahwa ia telah menyerahkan nyawa-Nya untuk kita; jadi kitapun wajib menyerahkan nyawa kita untuk saudarasaudara kita. ${ }^{40}$

\section{Mengasihi sesama berarti} mengorbankan diri sendiri untuk sesama supaya mereka hidup atau tidak binasa. John Chrysostom menegaskan: "You should love one another because you are brothers and have been born from the same spiritual womb...There is nothing which makes friends so much as the earnest

24, 28, 31; 15: 9 (2 kata), 12 (2 kata), 19; 16:27 (2 kata); 17:23 (2 kata), 24; 21:15 (2 kata), 16 (2 kata), 17 (3 kata), Rom 8:27, 37; 9:13; 12:10;13:8 (2 kata), 1 Kor $2: 9 ; 8: 3 ; 16: 22,2$ Kor $2: 8 ; 9: 7 ; 11: 11 ; 12: 15$, Gal 2:20, Efe 5:2, 25, 28 (3 kata); 6:24, 1 Tes 3:12; 4:9, 2 Tes 2:10,16, 2 Tim 3:3, Tit 2:4;3:15, Yak 1:12; 12:5, 1 Ptr 1:22; 3:8, 1 Yoh 2:10, 15 (2 kata); 3:10,11, 14 (2 kata), 23; 4:7 (2 kata), 8, 10 (2 kata), 11 (2 kata), 12, 19 (2 kata), 20 (3 kata), 21 (2 kata); 5:1 (2 kata), 2 (2 kata), 2 Yoh 1:1, 5, Why 1:5; 3:19; 12:11.

${ }^{37}$ Mat 5:43,44; 19:19; 22:37, 39, Mrk 12:30, 31, Luk 6:27, 35; 10: 27 (2 kata), Yoh 15:17, Rom 13:9, Gal 5:14, Efe 5:25,33, Kol 3:19, Yak 2:8, 1 Ptr $2: 17 ; 4: 8$.

${ }^{38}$ LAI, 1 Yoh 4:16.

${ }^{39}$ Yakub Susabda, mengenal dan bergaul dengan Allah (Batam: Gospel Press, 2001), 49.

${ }^{40} \mathrm{https}: / /$ hendisttrii.wordpress.com/2019/02/ 14/outline-konsep-markus-12-29-30/, (diakses 7 April 2019) 
endeavor to overcome one's neighbor by honoring him. ${ }^{41}$ Artinya karena kita lahir dari Rahim spiritual yang sama maka marilah kita mengasihi. Mengasihi selalu di sertakan dengan tindakan, baik memberi secara fisik, maupun abstak melalui nasehat. Pemberian yang baik adalah pemberian yang tidak mengaharapkan imbalan, atau dengan kata lain CumaCuma. Hal utama yang telah dilakukan oleh Kristus kepada kita adalah memberikan diri-Nya sehingga kita mendapat keselamatan. Di sisi lain mengasihi juga di ikuti oleh ketaatan, artinya tidak berhenti pada bagian tertentu, atau tidak dapat dipengaruhi oleh keadaan dan sikap hati, melainkan taat sampai mati. Hal ini membuktikan dengan adanya ketatan Yesus sampai mati. Yang dapat dipastikan bahwa ketaatan Yesus bersifat aktif dan sukarela. Martin, mengutip Lohmayer, menulis bahwa ketaatan Yesus sampai mati mengungkapkan Yesus sebagai the true God-become-men, for only a divine being can accept death as obedience; for ordinary men (and woman) it is a necessity, to which they are appointed by their humanity. ${ }^{42}$

Arman Barus menambahkan bahwa kematian Yesus dikayu salib memperlihatkan puncak ketaatan-Nya. Batas akhir ketaatan Yesus mencapai kematian penyaliban. Kematian Yesus di kayu salib bukan menyingkapkan identifikasi sempurna dengan keberdosaan manusia, tetapi menunjuk kepada ketaatan

\footnotetext{
${ }^{41}$ Catena Aurea all commentaries

${ }^{42}$ Arman Barus, "Kerendahan hati, ketaatan, dan kemuliaan Kristus" studi surat Filipi 2:611:Jurnal Teologi Reformed Indonesia, Vol 3 no 2 Juli 2013, 94.
}

sempurna sebagai manusia, karena bersifat sukarela dan aktif. ${ }^{43}$

Hidup di Dalam Terang

Satu bagian Alkitab yang mendeskripsikan mengenai hidup di dalam terang terdapat pada surat 1 Yohanes 1:7. Kata $\pi \varepsilon \rho \iota \pi \tau \tilde{\omega} \mu \varepsilon v$ menurut Low Nida Lexicon memiliki dua pengetian yang pertama "walk" dan kedua "behave". Dari kedua pengertian tersebut selalu dikaitkan dengan aksi atau tindakan. Sebab tidak dikatakan orang berjalan sementara masih berdian pada posisi yang sama, atau tidak disebut seorang berperilaku baik kalau tidak dapat menunjukkan bahwa ia berperilaku baik. Oleh sebab itu orang yang mau hidup di dalam terang harus beranjak pada tahap berikutnya, yakni menyarahkan diri untuk dibaptisan sehingga menjadi anak-anak Allah dan itulah manusia baru atau ciptaan baru di dalam Kristus (Yoh 3:5; Mrk 16:16; 1 Yoh 5:1; 3:9; Efe 4:24; Gal 6:15; 2 Kor 5:17). Ini merupakan salah satu tahap pengenalan akan Allah yang di tuliskan oleh Yakub Suabda: ia menuliskan bahwa pengenalan yang sejati akan Allah ada dalam konteks peristiwa kelahiran baru itu sendiri. $^{44}$ Manusia baru adalah manusia batiniah yaitu jiwa dan roh kita yang terlahir kembali dan sekarang sedang diperbarui dari hari ke hari sehingga roh dan jiwa itu bisa semakin bertumbuh dewasa seperti Kristus (Rom 12:2; Efe 4:13,15,23-24).

Manusia baru juga meliputi manusia lahiriah atau tubuh jasmani. Tubuh kita di

\footnotetext{
${ }^{43}$ Arman Barus, "Kerendahan hati, ketaatan, dan kemuliaan Kristus" studi surat Filipi 2:611:Jurnal Teologi Reformed Indonesia, Vol 3 no 2 Juli 2013, 95.

${ }^{44}$ Yakub Susabda, mengenal dan bergaul dengan Allah (Batam: Gospel Press, 2001), 82.
} 
dalam manusia baru adalah bait Roh Kudus yang harus dipersembahkan kepada Allah dalam kekudusan (Rom 12:1; 1 Kor 6:19; 3:17). Sehingga manusia baru baik manusia batiniah dan manusia lahiriah ini harus terus menerus diperbarui (Kol 3:10). Pembaruan ini adalah proses pengudusan atau pemurnian atau purifikasi atau askesis menuju kedewasaan dalam Kristus. ${ }^{45}$ Ketika kita dimurnikan maka kita akan mendapatkan pikiran yang baik seperti pikiran Kristus. Nous yang baik adalah Nous yang diperbarui oleh Roh Kudus sehingga dari dalam batin akan terpancar terang keluar dari tubuh dalam wujud perbuatan-perbuatan baik. Kata Yesus, "Sebab dari dalam, dari hati orang, timbul segala pikiran jahat, percabulan, pencurian, pembunuhan," (Markus 7:21). Kita adalah terang dunia kata Tuhan Yesus (Mat 5:14). Kita adalah anak-anak terang atau anakanak siang kata Rasul Paulus (1 Tes 5:5). Kita adalah manusia baru yaitu manusia terang. Ini berarti dari dalam yaitu batin atau hati kita mengalir energi terang sehingga ada sinar atau cahaya yang terpancar keluar dari tubuh kita. Seperti pelita atau lampu kata Tuhan Yesus. Lampu bisa jadi terang karena ada energi listrik atau energi api yang mengalir di dalam lampu/pelita itu.

Kita menjadi anak terang karena ada energi ilahi yang mengalir masuk ke dalam batin kita yaitu Nous kita. Nous ini diterangi oleh energi dari Allah melalui Roh Kudus. Nous ini yang bersentuhan dengan energi ilahi melalui interaksi Nous dengan Roh Kudus. Hanya Roh Kudus yang mencurahkan kasih Allah dalam wujud kasih karunia atau anugerah Allah (Rom 5:5), yang mengajar ajaran atau Nous

\footnotetext{
${ }^{45}$ https://hendisttrii.wordpress.com/2018/09/ 30/manusia-baru-manusia-terang/ (diakses 8 April 2019).
}

118 | Vol. 4 No. 2 (Desember 2020)
Kristus (Yoh 14:26; 16:13), yang mengetahui segala sesuatu tentang Allah (2 Kor 2:10-11). Sehingga ketika Nous berinteraksi dengan Roh Kudus ada aliran energi Allah atau anugerah dalam wujud Nous Kristus ke dalam hati kita sehingga hati kita dipenuhi energi itu. ${ }^{46}$

\section{Serupa dan Segambar Dengan Kristus}

Kita tahu bahwa manusia diciptakan serupa dan segambar dengan Allah (Kej 1:16), tetapi banyak orang yang tidak memahami apa itu serupa dan segambar, dan banyak orang yang berpendapat bahwa Tuhan meiliki rupa dan gambar yang banyak sebab dilihat dari rupa manusia berbeda-beda. Namun jika di pelajari lebih dalam bahwa gambar dan rupa Allah merupakan pusat teologi, seperti yang dituliskan oleh peorang penulis bernama Andrew Louth demikian: "Now this theme of image is, in theology of fathers, above all the Greek father, truly central: there one sees at the same time the meeting of Christology and trinitarian theology, of anthropology and psychology, of the theology of creation and that of grace, of the problem of nature and the supernatural, the mystery of divinization, the theology of spiritual life, the laws of its development and of its progress. ${ }^{47}$ Itulah alasan Andrew dari pernyataannya bahwa gambar dan rupa Allah merupakan pusat teologi, karena seperti yang ia jelaskan, di dalam rupa atu gambar Allah berbicara mengenai Kristus dan Allah Tritunggal, ilmu antropologi dan

\footnotetext{
${ }^{46} \mathrm{https}: / /$ hendisttrii.wordpress.com/2018/09/ 30/manusia-baru-manusia-terang/ (diakses 8 April 2019).

${ }^{47}$ Andrew Louth, Introducing Eastern Orthodox Theology (Downers Grove: Inter Varsity Press, 2013), 82. Dikutip dari Th. Camelot OP,'La theologie de Dieu,' Revue des Sciences philosophiques et theologiques XL (1956),443-71; here 443-4.
} 
psikologi bahkan secara misteri membahas alam dan supranatural.

Pada umumnya pengertian yang kita dapatkan dari, guru agama maupun pemimpin agama yang berkaitan dengan gambar dan rupa Allah adalah, karena manusia di karuniakan akal budi, dan kehendak bebas. Hal yang sama di tuliskan oleh Andrew yang dikutip dari perkataan John Damascene demikian: 'is manifest in inteligence (noeron) and free will (autexousion). Being in the image means being a rational, or inteligent, being free will. $^{48}$ Disisi lain manusia tidak hanya memiliki akal budi, dan kehendak bebas tetapi juga harus memiliki kedekatan yang erat untuk mengenali Kristus secara pribadi dengan berkomunikasi melalui doa sebagai bentuk relasi yang erat dengan Dia. Hal yang serupa dituliskan oleh Andrew dalam bukunya yang berjudul "Introducing Eastern Orthodox Theology" demikian:

What I am arguing is that limiting being in the image of God to being rational and possessing free will fall short in two respect of what the Greek Fathers generally mean by being according to God's image. first, being logikos means more than simply being rational; it means participating in the logos, the word, of God, including rationality, certainly, but also a capacity for recognizing and conveying meaning, for communicating, with one another and with God, and untimately an affinity witg God, that enables us to Know him. second, possessing to kat' eikona means

${ }^{48}$ Andrew Louth, Introducing Eastern Orthodox Theology (Downers Grove: Inter Varsity Press, 2013), 85. having a realtionship to God through his image, that is, the Word; it is not just a property or a quality, but a capacity for a relationship, a relationship that is fulfilled in attainment of to kath' omoiosin, being according to the likeness, assimilation with God. ${ }^{49}$

Kemudian Andrew lebih menegaskan bahwa Kristus yang menjadi pola kita diciptakan sehingga kita bisa datang untuk mengetahui tentang Allah olek kasih karunia melaui Roh, berikut yang tuliskannya: To think of the human as' according to the image' in this sense sets up a pattern: we have been created by God the Father in the image of the Word through the Word, so that, through the Word who created us we might come to the knowledge of God the Father- his whole proses takes place by the grace, that is, through the spirit. $^{50}$

Athanasius menambahkan bahwa tidak hanya itu, manusia diciptakan juga berbeda dari makhluk ciptaan lain, ia menuliskan demikian "Creating human being not simply like all the irrational animals upon the earth, but making them according to his own image, and giving them a share of the power of his own Word, so that having as it were shadows of the Word and being made rational, they might be able to abide in blessedness, living the true life, which is really that of the holy one in paradise. ${ }^{51 "}$ Kemudian ia menekankan

${ }^{49}$ Andrew Louth, Introducing Eastern Orthodox Theology (Downers Grove: Inter Varsity Press, 2013), 86.

${ }^{50}$ Andrew Louth, Introducing Eastern Orthodox Theology (Downers Grove: Inter Varsity Press, 2013), 87.

${ }^{51}$ Andrew Louth, Introducing Eastern Orthodox Theology (Downers Grove: Inter Varsity Press, 2013), 85. 
bahwa gambar dan rupa Allah itu merupakan hadiah bagi kita, dan gambar Allah itu sendiri adalah Kristus. Berikut yang dituliskan oleh Athanasius: "Being in the image is a gift to humanity, body dan soul, which grants rationality to human, but must mean more than this. The more is, I think, for Athanasios, tied up whith the fact that image of God is Christ, the word of God, whom we cannot understand apart from incarnation. it is in some way according to the image of God, understood as the word of god incarnation, the human kind was fashioned. ${ }^{52}$

Hal yang serupa dituliskan oleh Arkhimandrit Daniel Bambang, dalam bukunya yang berjudul "Allah Tritunggal", bahwa gambar Allah adalah Firman Allah itu sendiri. Berangkat dari pengertian bahwa dalam bahasa asli Perjanjian Baru yaitu bahasa Yunani kata " Gambar Wujud Allah" adalah tertulis "Kharakteer tess Hypostaseoos Autou”. Dengan demikian "Anak Allah" atau "Firman Allah" adalah "Karaktir" yang arti sebenarnya adalah stempel/ cap dari Allah. Gambar dari stempel yang tidak ada bedanya sama sekali dengan gambar yang ada pada stempelnya itu sendiri. Sehingga "Anak Allah" atau "Firman Allah" yang dipahami menjadi "Gambar Allah" yang adalah "Gambar tindasan" secara tepat, persis tidak ada bedanya sedikitpun dari Wujud Allah (Bapa) sendiri. ${ }^{53}$

Alkitab Perjanjian baru juga memberikan rincian dengan begitu jelas bahwa Kristus merupakan Gambar Allah (Kol 1:15 dan Ibr 1:3), Ia juga rupa Allah (Flp 2:6). Menurut Kamus Besar Bahasa

${ }^{52}$ Andrew Louth, Introducing Eastern Orthodox Theology (Downers Grove: Inter Varsity Press, 2013), 86.

${ }^{53}$ Daniel Bambang, Allah Tritunggal (Jakarta: Satya Widya Graha, 2001), 167. 120 | Vol. 4 No. 2 (Desember 2020)
Indonesia (KBBI), gambar adalah tiruan barang yang dibuat dengan coretan pensil. Dalam bahasa Yunani gambar adalah

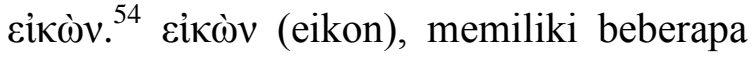
pengertian. Menurut St.Darmawijaya dalam bukunya yang berjudul Gelar-gelar Yesus, ada enam pengertian eikon, ${ }^{55}$ diantaranya:

1. Eikon berarti penampakan dalam gagasan. Misalnya Euripides bercerita bagaimana Hercules ditahan karena mengamuk atas penampakan Dewi Athena.

2. Eikon berarti kesan. Misalnya bila seseorang mendengar suara atau melihat sesuatu, orang itu lalu membentuk gambaran tertentu, entah tepat atau kurang tepat.

3. Eikon berarti persamaan, perbandingan. Misalnya orang itu seperti anak kecil, atau kera itu mirip.

4. Eikon berarti gambar dalam cermin. Misalnya Euripides bercerita tentang Medea yang menjalin rambutnya di depan kaca, kemudian tersenyum melihat gambar dirinya.

5. Eikon berarti gambar, pepetan, arca yang menampilkan persamaan dengan realitasnya.

6. Eikon berarti foto atau copy dari kenyataan. Atau dalam dokumen resmi, eikon berarti gambaran teliti akan pribadi yang tercantum dalam dokumen itu.

Dari beberapa pengertian diatas, maka dapat disumpulkan bahwa Yesus adalah citra Allah yang sejati dan ini adalah keyakinan iman Kristen. ${ }^{56}$ Bahkan Paulus menuliskan bahwa dia lebih utama ada

\footnotetext{
${ }^{54}$ LAI, Kol 1:15.

${ }^{55}$ Darmawijaya, Gelar-gelar Yesus (Yogjakarta: Kanisuius, 1987), 246-247.

${ }^{56}$ Darmawijaya, Gelar-gelar Yesus (Yogjakarta: Kanisuius, 1987), 248.
} 
sebelum yang lain ada (Kol 1:15). Jika di dalami kata "Kita" dalam permulaan penciptaan manusia (Kej 1:26) adalah kata ganti orang pertama jamak artinya terdiri dari beberapa pribadi, diantaranya Allah, Firman dan Roh kudus. Dalam Perjanjian Lama Firman masih dalam bentuk ucapan Allah, namun dalam Perjanjian Baru Firman itu sudah berinkarnasi menjadi manusia, yang dapat dilihat oleh manusia. Ia adalah Kristus yang menjadi penyelamat umat manusia karena dosa. Pertanyaannya, bagaimana kita menjadi serupa dan segambar dengan Kristus?

Hal mendasar yang dialami oleh manusia untuk serupa dan segambar dengan Kristus yaitu kebangkitan roh dan jiwa yang mati karena dosa melalui iman dan baptisan dalam karya Roh Kudus; pertumbuhan roh dan jiwa sampai kedewasaan penuh sama seperti Kristus; dan kebangkitan tubuh dengan mengenakan tubuh yang mulia dan dipersatukan dengan jiwa roh yang telah dewasa. ${ }^{57}$ Dalam hal ini berkaitan dengan pertobatan, sebab tidak ada lagi manusia yang tidak berdosa melainkan setiap insan manusia telah melakukan dosa (Rom 3:23), sehingga perlu kebangkit dari keterpurukan itu untuk menyerahkan diri dibaptis, sebagai bukti pertobatan kita dari dosa. Tidak hanya berhenti pada kebangkitan tetapi kita terus bersinergi dengan Kritus. Bersinergi dengan Kristus melalui doa sebagai wujud relasi kita dengan Tuhan dan sesama.

Salah satu tim riset, yang terdiri dari Renske Kruizinga, Michael Scherer-Rath dkk, menuliskan hal yang serupa yakni kita harus memiliki relasi yang erat dengan

\footnotetext{
${ }^{57}$ https://hendisttrii.wordpress.com/2018/12/ 16/manusia-gambar-dan-rupa-allah/ (diakses 14 April 2019).
}

Tuhan dan sesama sebagai wujud kita diciptakan serupa dan segambar dengan Dia, berikut yang dituliskan mereka: "a personal Image of God was weakly related to Existential wellbeing, Relationship with Self and Relationships with Others, while it was strongly related to Relationship with Something Greater (and moderately also with Relationship with God. ${ }^{58}$ Dari beberapa penjalasan misalnya dalam hal berdoa adalah hal yang abstrak yang tidak bisa diketahui dan diilhat oleh orang lain tetapi, tetapi dalam hal mengasihi adalah hal yang dapat dilihat oleh orang lain sebagai wujud nyata bahwa kita serupa dan segambar dengan Tuhan, sebab disaat kita mengasihi selalu disertakan dengan tindakan. Mengasihi adalah salah satu karakter Kristus yang dapat kita teladani, bahkan Allah bapa itu sendiri adalah kasih, (1 Yoh 4:8,16).

Menjadi serupa dan segambar dengan Kristus, manusia yang mestinya diharuskan untuk hidup kudus (1 Ptr 1:16) dan Suci (1 Yoh 3:3), karena Dia adalah kudus dan suci. Penyucian atau purifikasi ini dilakukan oleh manusia untuk membersihkan hawa nafsu dan melakukan perbuatan baik. Siklus ini menghasilkan berbagai macam perbuatan baik yang puncaknya adalah kasih. Melalui perbuatan baik yang puncaknya adalah kasih membawa kita pada tahap kontemplasi dan mencapai mystical knowledge yaitu hidup hanya terfokus pada Allah saja dan mencapai kemanunggalan

\footnotetext{
${ }^{58}$ Renske Kruizinga, Images of God and attitudes towards death in relation to spiritual wellbeing: an exploratory side study of the EORTC QLQ-SWB32 validation study in palliative cancer patients (Kruizinga et al. BMC Palliative Care (2017), 4 .
} 
dengan Allah atau menyatu dengan Kristus, demikian yang dituliskan oleh Hendi. ${ }^{59}$

Seperti kata Rasul Paulus yang sudah menjalani purifikasi, kontemplasi, dan mystical knowledge dengan menuliskan, "Hidup adalah Kristus dan mati adalah keuntungan" (Fil 1:21); "sambil berpegang pada firman kehidupan, agar aku dapat bermegah pada hari Kristus, bahwa aku tidak percuma berlomba dan tidak percuma bersusah-susah. Tetapi sekalipun darahku dicurahkan pada korban dan ibadah imanmu, aku bersukacita dan aku bersukacita dengan kamu sekalian." (Fil 2:16-17). Rarul Paulus telah mencapai puncak virtues sehingga dia mengalami dispassion dalam segala hal seperti yang dia tuliskan, "Kukatakan ini bukanlah karena kekurangan, sebab aku telah belajar mencukupkan diri dalam segala keadaan" (Fil 4:11). Dan mencapai kasih dalam segala hal yaitu pengorbanan dirinya untuk Gereja Tuhan (Fil 2:16-17) dan kita tahu bahwa kasih yang tertinggi adalah pengorbanan nyawa seperti yang dituliskan oleh Rasul Yohanes, "Demikianlah kita ketahui kasih Kristus, yaitu bahwa Ia telah menyerahkan nyawa-Nya untuk kita; jadi kita pun wajib menyerahkan nyawa kita untuk saudara-saudara kita" (1 Yoh 3:16).

Purifikasi yang demikian membawa Rasul Paulus pada tahap kontemplasi yaitu fokus kepada Allah saja bukan hal-hal dunia lagi. Dia mengatakan, "Jadi akhirnya, saudara-saudara, semua yang benar, semua yang mulia, semua yang adil, semua yang suci, semua yang manis, semua yang sedap didengar, semua yang disebut kebajikan dan patut dipuji, pikirkanlah semuanya itu" (Fil 4:8) dan "Malahan segala sesuatu kuanggap rugi, karena pengenalan akan Kristus 122 | Vol. 4 No. 2 (Desember 2020)

\footnotetext{
${ }^{59}$ https://hendisttrii.wordpress.com/2018/08/
18/purifikasi-siklus-askesis/ diakses pada tangga 16

${ }^{59}$ https://hendisttrii.wordpress.com/2018/08/
18/purifikasi-siklus-askesis/ diakses pada tangga 16 April 2019, 13:04.
}

Yesus, Tuhanku, lebih mulia dari pada semuanya. Oleh karena Dialah aku telah melepaskan semuanya itu dan menganggapnya sampah, supaya aku memperoleh Kristus," "Yang kukehendaki ialah mengenal Dia dan kuasa kebangkitanNya dan persekutuan dalam penderitaanNya, di mana aku menjadi serupa dengan Dia dalam kematian-Nya," "Saudarasaudara, aku sendiri tidak menganggap, bahwa aku telah menangkapnya, tetapi ini yang kulakukan: aku melupakan apa yang telah di belakangku dan mengarahkan diri kepada apa yang di hadapanku, dan berlarilari kepada tujuan untuk memperoleh hadiah, yaitu panggilan sorgawi dari Allah dalam Kristus Yesus" (Fil 3:8,10,13-14).

Tahap kontemplasi membawa Rasul Paulus pada tahap mystical knowledge yaitu kerinduan akan penyatuan dengan Allah, dengan mengatakan bahwa hidup dia adalah Kristus dan mati adalah sebuah keuntungan (Fil 1:21). Dia menuliskan, "Sebab yang sangat kurindukan dan kuharapkan ialah bahwa aku dalam segala hal tidak akan beroleh malu, melainkan seperti sediakala, demikian pun sekarang, Kristus dengan nyata dimuliakan di dalam tubuhku, baik oleh hidupku, maupun oleh matiku" (Fil 1:20). Penekanan yang mendasar seperti yang dituliskan oleh Rasul paulus dalam suratnya di jemaat Filipi bahwa keserupaan yang dialaminya melalui kematian Kristus, supaya memperoleh kebangkitan. Sebab tanpa kematian tidak ada kebangkitan. Kematian yang dialami oleh manusia bukanlah kematian tubuh, tetapi kematian secara jasmani dan rohani, yakni mematikan hawa nafsu seperti yang dialami oleh Rasul Paulus. 
Bagaimana cara mengerjakannya: Menyucikan diri dari segala nafsu duniawi

Untuk mencapai Theosis maka manusia harus menyucikan diri, sebab Allah adalah kudus, Im 19:2; 20:7, 26, 1 Ptr $1: 16$. Kudus atau suci merupakan salah satu sifat Allah yang manusia kerjakan untuk mencapai penyatuan tersebut. Manusia mengalami sendiri kehadiran Allah dalam hidupnya, melalui sinar kemuliaan yang keluar dari zat Allah lewat alam ciptaan. Dan sinar itu tidak diciptakan melinkan keluar dari diri Allah. Melalui sinar yang tidak diciptakan itulah yang kalau menyentuh benda duniawi dan manusia maka manusia dimampukan untuk melihat sifat-sifat Allah itu, yakni kasih, kesucian, kebesaran, kemuliaan, dan kemurnian. ${ }^{60}$

Diantara sifat Allah itu yang lebih utama dari segalanya adalah Kasih. 1 Yoh 4: 8, 16 menegaskan bahwa Allah adalah kasih, dan agar kita tetap tinggal di dalam Allah maka kita harus saling mengasihi. Bahkan seorang penulis bernama Donald G. Bloesch menuliskan bahwa dalam Allah hanya ada dua sisi yaitu kekudusan dan kasih. Berikut yang dituiliskannya: "God as having two sides: holiness and love. these are the perfections that shape the interaction of God with his people. They are integrally related, and yet hey coexist in a certain tension, one that highlights their paradoxical unity rather than dissolves it. ${ }^{61}$ Tidak hanya itu, Donald justru memberikan penjelasan ada apa dibalik kesucian dan kasih Allah itu? Demikian yang dijelaskannya: "God's holiness is his

\footnotetext{
${ }^{60}$ Daniel Bambang, Allah Tritunggal (Jakarta: Satya Widya Graha, 2001), 90.

${ }^{61}$ Donald G. Bloesch God The Almighty (USA: Inter Varsity Press,1995), 139.
}

majestic purity that cannot tolerate moral evil. God's love is his outgoing, tenderhearted embrace of sinner. God's holiness is his separateness from what is unclean and profane. God's love is his willingness to identity with those who are unclean in order to help them. God's holiness transcends the passing world of decay and death. God's love incarnates itself in this world corrupted by sin. ${ }^{62}$

Selanjutnya Donal menuliskan bahwa kasih dan kekudusan Allah merupakan sifat batiniah dari Allah yang hidup. Kedua kesempurnaan ini bersatu sedemikian rupa sehingga kita dapat berbicara tentang cinta suci Allah dan tentang kekudusannya yang penuh belas kasihan. Dan keduanya berkaitan satu dengan yang lain. Di kedalaman kasih Tuhan terungkap keindahan kekudusanNya. Dalam kemuliaan kekudusan-Nya terbentang luasnya kasihnya. Puncak kekudusan Allah adalah kekudusan kasihNya, demikian yang dituliskan Donald:

From my perspective God's love and holiness constitute the inner nature of the living God. These two perfections coalesce in such a way that we may speak of the holy love of God (as did Forsyth) and of his merciful holiness. In the depth of God's love is revealed the beauty of his holiness. In the glory of his holiness is revealed the breadth of his love. The apex of God's holiness is the holiness of his love. The apex of God's love is the beauty of his holiness. God's love transcends his holiness even while it infuses and upholds it. His holiness is adorned

${ }^{62}$ Donald G. Bloesch God The Almighty (USA: Inter Varsity Press, 1995), 140. 
and crowned by the magnitude of his love. ${ }^{63}$

Kekudusan Allah sudah dikumandangkan dari jaman Perjanjian Lama, sampai Perjanjian Baru. 1 Ptr 1:16, menekankan bahwa Allah adalah Kudus. Hal ini dikutip dalam Perjanjian Lama, Im 11: $44-45$, yang berkata demikian: “44 Sebab Akulah TUHAN, Allahmu, maka haruslah kamu menguduskan dirimu dan haruslah kamu kudus, sebab Aku ini kudus, dan janganlah kamu menajiskan dirimu dengan setiap binatang yang mengeriap dan merayap di atas bumi. ${ }^{45}$ Sebab Akulah TUHAN yang telah menuntun kamu keluar dari tanah Mesir, supaya menjadi Allahmu; jadilah kudus, sebab Aku ini kudus. ${ }^{64,}$

Anthony menuliskan bahwa penyucian merupakan proses pertumbuhan bertahap di dalam Kristus, dengan mengenakan Kristus dan menerima Roh Kudus, melalui doa dan sakramen, berikut yang dituliskannya: "Sanctification, which is the process of being sanctified or made holy. This is the Christian's gradual growth in Christ. It includes the putting on of Christ and the receiving of the Holy Spirit. Here prayer and the sacraments play an important role". ${ }^{65}$ Dari pendapat Anthony diatas, timbul pertanyaan bagaimana kita mengenakan Kritus dan menerima Roh kudus? Mengenakan Kristus berarti membiarkan Kristus yang hidup di dalam diri kita dengan penyerahan diri seutuhnya, sama seperti yang dialami oleh Paulus, bahwa bukan aku lagi yang hidup melaikan Kristus yang hidup di dalam aku (Gal 2:20). Permulaan kita mengenakan Kristus, ketika

\footnotetext{
${ }^{63}$ Donald G. Bloesch God The Almighty (USA: Inter Varsity Press,1995), 141.

${ }^{64}$ LAI, Im 11:44-45.

${ }^{65}$ Antony.M.Coniaris Introducing the Orthodox Church its faith and life (Minneapolis: Light and Life Publishing Company, 1982), 187.

124 | Vol. 4 No. 2 (Desember 2020)
}

dibaptis sehingga kita pun menerima Roh Kudus. Namun pada permulaan penciptaan kita telah menerima Roh kudus sebab, Roh adalah nafas yang dihembuskan Allah sehingga manusia yang dicpatakan-Nya bernafas. Dan roh yang sama, kita terima ketika dibaptis, sebab kita telah dicemari oleh dosa yang membuat hubungan kita terputus dengan Tuhan (Rom 3:23).

Ketika kita mencapai puncak penyucian yang dimaksud oleh Anthony, kita menjadi manusia baru, karena kita diciptakan kembali dengan kebenaran dan kekudusan yang sesungguhnya (Ef 4:24) dan yang diperbarui terus menerus (Kol 3:10). Pembaharuan itu terus dikerjakan dengan berdoa dan melakukan sakramen. Dan sakramen yang mempersatukan kita kepada Kristus adalah sakramet Ekaristi/ Perjamuan Kudus, sebab sakrament ini mengingatkan kita akan pengorbanan Kristus dengan memakan daging dan minum darah-Nya. Bahkan Norman menuliskan bahwa Ekaristi merupakan pusat kehidupan rohani di dalam Kristus, berikut yang dituliskannya:

"The eucharist is the center of the spiritual life in Christ and its source. Here the union with Christ is complete and full. The whole person in all its dimensions, with all its psychosomatic senses and functions, is joined in a deep union with Christ, is transformed and christified. "This is the celebrated marriage by which the most holy bridegroom takes the Church as His virgin bride . . by this we become 'flesh of His flesh and bone of His bones' ( cf. Gen 2:2 1). "The divine eucharist makes "Christ our supreme good, superior to 
everything in us that is naturally good. $^{66}$

Sementara itu untuk mengantarkan kita pada setiap sakramen adalah doa. Sebagian orang tidak dapat menyisihkan waktu untuk berdoa karena sibuk dan tidak ada waktu namun sebelum lebih jauh kita membahas mengenai doa, mari kita melihat berapa definisi bapak gereja mengenai doa. (a) Prayer is "to stand with the mind in the heart before God, and to go on standing before Him unceasingly day and night, until the end of life". Prayer is the test of everything...the source of everything...the driving force of everything...the director of everything. Prayer is the raising of the mind and heart to God in praise and thanksgiving to Him and in supplication for the good things that we need, both spiritual and physical (Theophan). (b) Prayer...uplifts and unites human beings with God (St. Gregory Palamas).

(c) Prayer is our personal communication system with our home base. Prayer is a booster cable from our depleted lives to the ever dependable power of God which never fails to start us up again. Prayer is the response of the soul to the love of God. Prayer is taking our burdens to God, knowing He will help us carry them and renew us for the journey. Prayer is the prelude to peace, the prologue to power, the preface to purpose, and the pathway to perfection (W.A. Ward).(d) Prayer is the destruction of fear (Fr. John of Kronstadt). (e) Prayer is a continual intercourse of the spirit with God (Evagrios Ponticus). ${ }^{67}$

\footnotetext{
${ }^{66}$ Norman Rusell, Deification in Christ the nature of human person (USA: Vladimir's Seminary Press, 1987), 127.

${ }^{67}$ Antony.M.Coniaris Introducing the Orthodox Church its faith and life (Minneapolis:
}

Dari beberapa definisi diatas dapat disimpulkan bahwa doa adalah sumber dari segalanya, bahkan yang mempersatukan kita dengan Tuhan, juga merupakan sistem komunikasi kita dengan Tuhan, yang membuat rasa takut kita untuk menghadapi sesuatu dihancurkan sehingga kita memiliki kekuatan baru dan membuat hubungan roh kita dengan Tuhan terus menerus terkoneksi.

Berkaitan dengan doa John Meyendorff menekankan bahwa doa adalah salah satu cara kita menyatu dengan Tuhan, dan itulah alasan mengapa kita harus berdoa, karena di dalam doa secara bertahap akan meninggalkan segala pikiran buruk dan dengan berdoa kita dimampukan untuk menyesuaikan diri dalam mengahadapi setiap permasalahan, Berikut yang dituliskannya.

Thus it proceeds by means of discursive reasoning. But in the other case, there is union. In the one case, the mind negates itself together with other beings, but in the other there is a union of the mind with God. It is of this that the Fathers speak when they say, "The end of prayer is to be snatched away to God." This is why the great Denys says that through prayer, we are united to God. For in prayer, the mind gradually abandons all relation with created things: first with all things evil and bad, then with neutral things capable of conformity to either good or ill, according to the intentions of the person using them. It is to this last category that all studies belong and

Light and Life Publishing Company, 1982), 337338 . 
the knowledge that comes through them. Hence the Fathers warn us against accepting the knowledge that comes from the Enemy at the time of prayer, so as not to be deprived of that which is superior. ${ }^{68}$ Maka berdoa bukanlah sesuatu yang lazim dilakukan. Dan inti dari doa itu sendiri adalah ucapan terima kasih kepada Tuhan. Seperti yang dituliskan oleh W.A. Ward "The pulse of prayer is praise. The heart of prayer is gratitude. The voice of prayer is obedience. The arm of prayer is service",69. Itulah perlunya kita berdoa, ibarat oksigen yang dihirup oleh setiap insan manusia dan segala makhluk sehingga bisa ada dan tumbuh. Bahkan St. Gregory of Nyssa menuliskan orang yang berdoa diibaratkan seorang anak yang berbicara kepada bapaknya. Demikian yang di tuliskan oleh Gregory: "It is necessary for us to persist in prayer which is like the leader in a circle of dancers which are the virtues. It joins the person who persists in prayer to God...." "The work of God is simple: it is prayer-children talking to their Father, without any subtleties. "70

\section{Bahkan Lossky menuliskan} Pengalaman mistis yang tidak terpisahkan dari jalan menuju persatuan hanya dapat diperoleh melalui doa dan doa. Dalam pengertian yang paling umum, setiap kehadiran manusia di hadapan Allah adalah doa; tetapi kehadiran ini harus menjadi sikap yang konstan dan sadar. Doa harus menjadi abadi, sama tidak terputusnya

\footnotetext{
${ }^{68}$ John Meyendorff, Gregory Palamas The Triads (United States of America: Paulist Press, 1983), 64.

${ }^{69}$ Antony.M.Coniaris Introducing the Orthodox Church its faith and life (Minneapolis: Light and Life Publishing Company, 1982), 339.

${ }^{70}$ Antony.M.Coniaris Introducing the Orthodox Church its faith and life (Minneapolis: Light and Life Publishing Company, 1982), 354.
}

126 | Vol. 4 No. 2 (Desember 2020) dengan pernapasan atau detak jantung, demikian yang dituliskan Lossky:

The mystical experience which is inseparable from the way towards union can only be gained in prayer and by prayer. In the most general sense, every presence of man before the face of God is a prayer; but this presence must become a constant and conscious attitude prayer must become perpetual, as uninterrupted as breathing or the beating of the heart. For this a special mastery is needed, a technique of prayer which is a complete spiritual science, and to which monks are entirely dedicated. The method of interior or spiritual prayer which is known by the name of 'hesychasm', is a part of the ascetic tradition of the Eastern Church, and is undoubtedly of great antiquity. ${ }^{71}$

Hal ini juga kita dapat pelajari dari selama pelayana Yesus di bumi, setiap apa yang dikerjakan selalu diawali dengan doa. Yesus telah memberikan kita contoh untuk selalu berdoa dalam segala hal, Anthony menuliskan salah satu praktek doa yang simpel yakni doa puja Yesus, yang berbunyi demikian: "Tuhan Yesus Kristus, Anak Allah, kasihanilah aku." Dan untuk melakukan doa ini secara efektif kita harus mengambil waktu sendiri dengan membuang segala pikiran kita dan fokus pada Kristus, seperti yang dituliskan oleh Anthony: "Sit down alone and in silence. Lower your head, shut your eyes, breathe out gently and imagine yourself looking into your own heart. Carry your mind, i.e., your thoughts, from your head to your heart. As

\footnotetext{
${ }^{71}$ Vladimir Lossky, The Mystical Theology of the Eastern Church (Paris: James Clarke Publishing, 1994), 216.
} 
you breathe out say: "Lord Jesus, have mercy on me." Say it moving your lips gently, or say it in your mind. Try to put all other thoughts aside. Be calm, be patient and repeat the process very frequently. ${ }^{72}$

Dari penjelasan sebelumnya bahwa setelah kita dibaptis maka kita menjadi manusia baru karena kita diciptakan kembali menurut kehendak Allah di dalam kebenaran dan kekudusan yang seaungguhnya (Efe 4:24). Pertanyannya apa itu manusia baru? Manusia baru adalah manusia batiniah yaitu jiwa dan roh kita yang terlahir kembali dan sekarang sedang diperbarui dari hari ke hari sehingga roh dan jiwa itu bisa semakin bertumbuh dewasa seperti Kristus (Rom 12:2; Efe 4:13,15,23-24). Manusia baru juga meliputi manusia lahiriah atau tubuh jasmani. Tubuh kita di dalam manusia baru adalah bait Roh Kudus yang harus dipersembahkan kepada Allah dalam kekudusan (Rom 12:1; 1 Kor $6: 19 ; 3: 17)$. Sehingga manusia baru baik manusia batiniah dan manusia lahiriah ini harus terus menerus diperbarui (Kol 3:10). Pembaruan ini adalah proses pengudusan atau pemurnian atau purifikasi atau askesis menuju kedewasaan dalam Kristus.

Dengan kata lain manusia baru juga disebut sebagai manusia terang atau anakanak terang yang telah dibebaskan dari segala dosa, dan kita tidak lagi hidup dalam kegelapan (1 Tes 5:5). Disebut anak-anak terang karena ada energi ilahi yang mengalir masuk ke dalam batin kita yaitu Nous kita. Nous ini diterangi oleh energi dari Allah melalui Roh Kudus. Nous ini yang bersentuhan dengan energi ilahi melalui interaksi Nous dengan Roh Kudus.

${ }^{72}$ Antony.M.Coniaris Introducing the Orthodox Church its faith and life (Minneapolis: Light and Life Publishing Company, 1982), 364.
Hanya Roh Kudus yang mencurahkan kasih Allah dalam wujud kasih karunia atau anugerah Allah (Rom 5:5), yang mengajar ajaran atau Nous Kristus (Yoh 14:26; 16:13), yang mengetahui segala sesuatu tentang Allah (2 Kor 2:10-11). Sehingga ketika Nous berinteraksi dengan Roh Kudus ada aliran energi Allah atau anugerah dalam wujud Nous Kristus ke dalam hati kita sehingga hati kita dipenuhi energi itu. ${ }^{73}$

Jadi menyucikan diri dari segala nafsu duniawi artinya mematikan diri dari segala dosa, yakni percabulan, kenajisan, hawa nafsu, nafsu jahat, keserakahan, penyembahan berhala. Ketika kita tidak dapat menjauhkan dari segala nafsu dunia itu maka kita tidak mendapat bagian dalam Kerajaan Allah, Gal 5:21. Oleh sebab itu semasa hidup kita, harus meyucikan diri dan mengasihi Tuhan dan sesama, serta melakukan sakramen dan berdoa, sehingga kita menjadi manusia baru atau anak-anak terang sebab kita sudah mendapat energi ilahi dari Kristus. Dengan demikian kita akan beroleh hidup yang dapat menyatu dengan Kristus.

\section{KESIMPULAN}

Setiap manusia yang percaya kepada Kristus akan mengalami kematian, namun dalam hal ini kematian secara tubuh, sebab roh tidak akan mengalami kematian sehingga roh akan kembali kepada gambar dan rupa yang sejati yakni menyatu dengan Kristus. Penggalian 2 Ptr 1:4 dan 20 ayat dari Perjanjian baru maka penulis menjdapat 3 point penting bagaimana manusia mecapai hidup yang menyatuan

\footnotetext{
${ }^{73}$ https://hendisttrii.wordpress.com/2018/09/ 30/manusia-baru-manusia-terang/ (diakses 4 Mei 2019).
} 
dengan Kristus. Dari ketiga poin dapat disimpulkan sebagai berikut:

Tinggal di dalam Allah di dalam energi berarti hidup dengan saling mengasihi dan tinggal di dalam terang. Energi adalah sesuatu yang keluar dari dalam diri Allah. Dan sesuatu yang keluar dari diri Allah adalah Firman-Nya, yang menjadikan segala sesutau itu ada dan Firman itu adalah Kristus (Yoh 1:1). Hidup saling mengasihi merupakan bukti atau wujud bahwa kita mengasihi Tuhan, sebab bagaimana mungkin kita mengasihi Allah yang tak terlihat semantara yang terlihat tidak kita kasihi? Oleh karena itulah manusia diharuskan untuk hidup saling mengasihi.

Hidup yang saling mengasihi akan mengantarkan kita pada kehidupan di dalam terang. Hidup di dalam terang berarti hidup yang telah diubahkan menjadi ciptaan baru dengan menyerahkan diri dibaptis sehingga disebut anak-anak Allah, atau anak terang. Jadi manusia tidak akan dapat mengalami Theosis kalau tidak tinggal di dalam Allah, karena diluar Allah kita tidak bisa berbuat apa-apa.

Serupa dan segambar dengan Kristus, artinya Rupa dan gambar Kristus dari sejak dahulu menempel dalam diri kita sebab kita dicipta menurut gambar dan rupa Allah. Gambar dan rupa Allah merupakan pusat teologi ke-Kristenan karena di dalam gambar dan rupa Allah terdapat Allah Tritunggal. Jika ditinjau dari awal mula penciptaan manusia kata "kita" sangat jelas menggambarkan akan Allah Bapa, Allah Anak, dan Allah Roh Kudus. Sekalipun manusia merupakan gambar dan rupa Allah, namun karena dosa manusia maka gambar dan rupa Allah itu menjadi kabur dan tak terlihat.

Oleh sebab itu untuk memulihkan gambar dan rupa Allah yang ada dalam diri 128 | Vol. 4 No. 2 (Desember 2020) manusia, maka manusia harus melakukan pertobatan dengan memberi diri dibaptis sehingga dibangkitkan kembali di dalam roh dan jiwa melalui kuasa karya Roh Kudus. Bahkan setelah kita memberi diri dibaptis kita menjadi ciptaan baru atau manusia baru. Manusia baru adalah manusia yang senantiasa bersinergi dengan Tuhan di dalam doa. Sehingga mempererat relasi kita dengan Tuhan. Salah satu riset menuliskan bahwa hubungan yang erat dengan Tuhan dan sesama merupakan wujud kita dalam kesupaan dan segambar dengan Allah. Jadi menjadi serupa dan segambar dengan Allah berarti serupa dengan Kristus. Keserupaan dengan Kristus dapat dialami melaui kematian sehingga mendapat kebangkitan. Karena tanpa kematian tidak ada kebangkitan.

Menyucikan diri dari segala nafsu dunia, artinya menjauhkan diri dari segala hawa nafsu dunia yang tersirat dalam Gal 5: 19-21 (percabulan, kecemaran, hawa nafsu, penyembahan berhala, sihir, perseteruan, perselisihan, iri hati, amarah, kepentingan diri sendiri, percideraan, roh pemecah, kedengkian, sebab tanpa adanya penyucian diri manusia tidak akan mengalami penyatuan bersama Krsitus sebab dia adalah kudus.

\section{DAFTAR PUSTAKA}

Bambang Daniel, Allah Tritunggal .Jakarta: Satya Widya Graha, 2001.

Barus, Arman "Kerendahan hati, ketaatan, dan kemuliaan Kristus" studi surat Filipi 2:6-11:Jurnal Teologi Reformed Indonesia, Vol 3 no 2 Juli 2013, 94.

Bloesch ,Donald G. God The Almighty .USA: Inter Varsity Press, 1995. 
Coniaris, Anthony M. Philokalia: The Bible of Ortodox Spirituality. Minneapolis: Light and Publishing Company, 1998.

Christopher Green, and Dick Lukas, The Message of 2 Peter \& Jude .England: Inter Varsity Press, 1995.

Dwi Byantoro, Arkhimandrit Bambang Gereja Orthodox Katolik dan Ajaran-ajarannya. Pdf.2007.

Darmawijaya, Gelar-gelar Yesus. Yogjakarta: Kanisuius, 1987.

Fallon, Michael M.S.C. "'The Joy of the Gospel-Some Points." Compass 49, no. 2 (Winter, 2015): 34; tersedia di http://search.proquest.com/docview/ 1703341415? accountid=25704; Internet; diakses tanggal 10 Februari 2016. Dikutip dalam sebuah disertasi Konsep Sukacita Di dalam Surat Filipi: Sebuah Pendekatan Integrasi Antara Analisis Wacana Dan Rentangan Semantis oleh Hendi tahun 2016. 2.

Hastings, James D.D, The speaker Bible The Epistle of James .USA: Baker House Company, 1987.

https://hendisttrii.wordpress.com/2018/05/0 6/tinggal-di-dalam-allah/.diakses 3 April 2019.

https://www.google.com/amp/makasar.tribu nnews.com/amp/2019/03/29/motifrasa-benci-jadi-alasan-2-pelakubunuh-telanjangi-pendeta-cantikmelinda-zidemi-fotonya .diakses 6 April 2019.

https://hendisttrii.wordpress.com/2019/02/1 4/outline-konsep-markus-12-29-30/ .diakses 7 April 2019.

https://hendisttrii.wordpress.com/2018/09/3 0/manusia-baru-manusiaterang/.diakses 8 April 2019.

https://hendisttrii.wordpress.com/2018/12/1 6/manusia-gambar-dan-rupa-allah/ .diakses 14 April 2019.

https://hendisttrii.wordpress.com/2018/08/1 8/purifikasi-siklus-askesis/ diakses pada tangga 16 April 2019, 13:04.
Louth, Andrew Introducing Eastern Orthodox Theology .Downers Grove: Inter Varsity Press, 2013.

Low Nida Lexicon

Martin James, "Have Faith in Joy." America 209, no. 19 (December 23, 2013), 13-16. Dikutip dalam sebuah disertasi Konsep Sukacita Di dalam Surat Filipi: Sebuah Pendekatan Integrasi Antara Analisis Wacana Dan Rentangan Semantis oleh Hendi tahun 2016. 2.

Meyendorff, John Gregory Palamas The Triads .United States of America: Paulist Press, 1983

Pfreiffer, Charles F. dan Everett F. Harrison, Tafsiran Alkitab Wycliffe volume 3 Perjanjian Baru. Malang: Yayasan Penerbit Gandum Mas, 1962.

Susabda, Yakub mengenal dan bergaul dengan Allah . Batam: Gospel Press, 2001.

Simanjuktak, A. dkk; Tafsiran Alkitab Masa Kini 3 Kejadian- Wahyu. Jakarta: Yayasan Komunikasi Bina Kasih, 2006.

William G. Morrice, Joy in the New Testament Grand Rapids: William B. Eerdmans, 1984), 152.

Warren, Rick. The Purpose Driven Life. Jakarta: Immanuel Publishing house, 2002. 